\title{
Comparative Analysis of Soil Physio-Chemical Properties of Two Different Districts Peshawar and Swabi, KP, Pakistan
}

\author{
Irum Rehman ${ }^{1}$, Hafeez Ur Rahim ${ }^{2 *}$ and Sumbul Rafiq ${ }^{1}$ \\ ${ }^{1}$ Department of Environmental Sciences, University of Peshawar, Pakistan \\ ${ }^{2}$ Department of Soil \& Environmental Sciences, University of Agriculture Peshawar, Pakistan
}

Submission: December 04, 2017; Published: December 14, 2017

*Corresponding author: Hafeez Ur Rahim, Department of Soil \& Environmental Sciences, University of Agriculture Peshawar, Pakistan, Email: hafeez.kalpani@aup.edu.pk

\begin{abstract}
The present research was designed to study and compare the physio-chemical properties of two different districts of Khyber Pakhtunkhwa, Pakistan i.e. Peshawar and Swabi. Ten soil samples from each district were collected at a depth of 10-15 cm from the selected sites and were analyzed for the different physical and chemical parameters. According to t-test, the Electrical Conductivity (EC), pH and Soil Organic Matter (SOM) were significant while the results of moisture content and bulk density were not significant. The results showed that there was a very little difference in the properties of soil of both districts. This change occurs due to the change in topography, weathering processes, climate, human activities. The soil of both districts is loam consisting equal amount of sand and silt and having less amount of clay which is good for farming. The bulk density of Swabi district soil is slightly higher than Peshawar district soil because of a little more sand content. The pH of soil of both districts is neutral which is suitable for agriculture. Moisture content of Swabi is less than Peshawar. As electrical conductivity may also depend upon texture, moisture and salts so the EC of Peshawar district is a little bit high than Swabi district. It was concluded that the properties of soil which were taken in account are depended on each other and affect the soil fertility and crop productivity and habitat sustainability, and the differences between the properties of both districts are due to agricultural practices, irrigation system, and use of fertilizers or may be due to some natural conditions. As soil is part of our ecosystem it is recommended that artificial fertilizers should be used in a proper way and in proper amount as it is not good for health. Crop rotation and good irrigation should be used in a proper manner in order to maintain the soil physio- chemical properties in good condition.
\end{abstract}

Keywords: Soil Physio-Chemical Properties; Comparative Analysis; Peshawar; Swabi

\section{Introduction}

As soil is an integral component of our environment, analyzing and understanding the status of the soil is important to guide farmers and other stakeholders and cultivation related issues and productive cropping. Soil, being an important natural resource for the survival and support of plants, should be studied thoroughly to identify its capability for suitable crops. For this reason soil physiochemical properties are studied to determine how the soil can affect the plant growth and crops productivity. World Bank report (2007) reaffirmed the role of agriculture in food security for the ever increasing population which, according to latest estimates, will reach 9 billion people by the year 2050 (UN 2008). As the linear expansion of land is not possible, in Pakistan rather it is shrinking due to construction of houses and development of infrastructure, there has been a trend of shifting agriculture towards steep lands. Soil erosion on these lands is one of the most significant ecological restrictions to sustainable agricultural production [1,2]. The on-site effects are particularly important which includes loss of clay particles, plant nutrients, organic matter, degradation of soil structure, decreased rooting depth and decrease in available soil water, all of which have a negative effect on soil productivity $[3,4]$.

According to Lal and Singh, soil degradation process in relation to crop productivity encompasses physical, chemical and biological degradation. Soil physical degradation can affect crop growth and yield by decreasing root depth, available water and nutrient reserves and soil erosion can lead to yield loss by affecting soil organic carbon, nitrogen, phosphorus and potassium contents and soil pH. Chemical degradation is caused by the processes of nutrient depletion and/or loss of organic matter, acidification and toxic aluminium, salinization and industrial and mining activities. This study has explored and analyzed various parameters of the samples collected from two districts of the Khyber Pakhtunkhwa (KP) province. The status of the soils of the selected areas is documented that can be used as a source for the effective management of the soil resources of the study areas. Peshawar and Swabi are the thickly populated areas of KP.

Agriculturally, these areas are important because main cash crops such as tobacco and sugarcane belong to these belts. These 
areas are mainly irrigated through river water which carries the dissolved salts which are gradually accumulated in these areas and thus affecting the soils with passage of time. That is why these areas are selected for our study to determine various physiochemical properties of the soils of Swabi and Peshawar.

There are different soil types in $\mathrm{KP}$, in order to familiar with such types of soil and soil properties we selected the comparative analysis of soil of Swabi and Peshawar. The Soil of both these areas has lots of minerals and heavy metals in various concentrations which affect the cash crop productivity therefore we selected these two areas for our research.

\section{Objectives of the study}

a. To find out the physio-chemical properties of soil of two districts (Peshawar and Swabi) of Khyber Pakhtunkhwa.

b. To compare the soil physio-chemical properties of two different geographic regions

\section{Methodology}

The present research was designed to study and compare the physio-chemical properties of two different districts of Khyber Pakhtunkhwa, Pakistan i.e. Peshawar and Swabi. Ten soil samples from each district were collected at a depth of 10-15 cm from the selected sites and were analyzed for the different physical and chemical parameters. Materials used for sampling were auger, shovel and sampling bags, cores etc. Samples were than packed in dry clean and unused plastic bags to retain its moisture. Bags were then labeled with sample number, and site. Samples were then brought to laboratory with great care to avoided rupturing of bags or mixing of soils for analysis. The physical parameters were include color, texture, bulk density, moisture content while the chemical parameters were include $\mathrm{pH}$, electrical conductivity and soil organic matter. The samples were analyzed in the lab and result were calculated and compared thereafter (Figure 1).

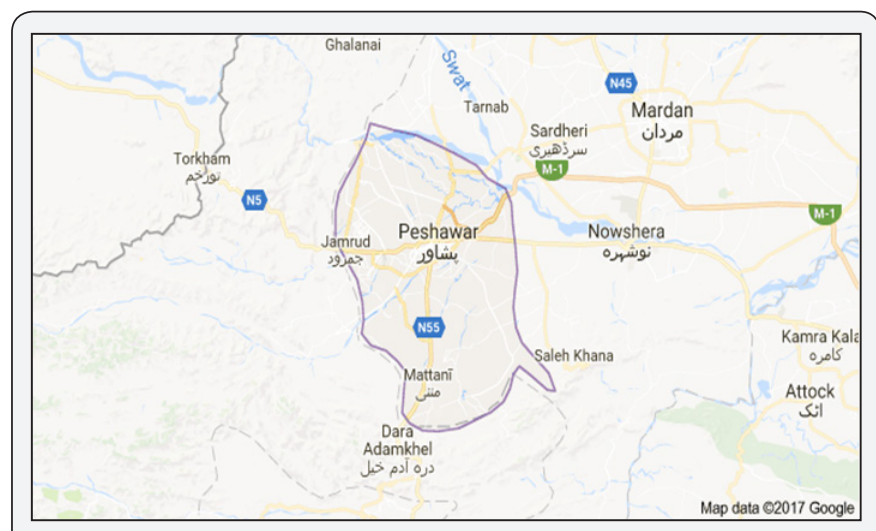

Figure 1: Sampling area of Peshawar Distract.

\section{Parameters which were under investigation}
a) Soil Physical Parameters:
i. Soil texture
ii. Moisture content
iii. Bulk density
b) Soil Chemical Parameters:
i. Soil $\mathrm{pH}$
ii. Soil EC
iii. Soil Organic Matter

\section{Analytical Procedures}

a) Soil Texture: Soil texture was determined by the hydrometer method as described by Gee and Bahadur [5].

b) Soil bulk density: Soil bulk density was determined by the method as described by the Blake and Hartage. The following formula was used for the determination of bulk density

$$
\mathrm{BD}=\mathrm{M} / \mathrm{V}
$$

c) Soil moisture content: Soil moisture content was determined by the method as indicated by Gardner. The following formula was used for the determination of bulk density

Soil moisture $=$ Soil fresh weight - Soil dry weight $/$ Soil dry weight X 100

d) Soil pH: Soil $\mathrm{pH}$ was determined by $\mathrm{pH}$ meter in $1: 5$ soil water suspensions as indicated by Smith et al [6].

e) Soil EC: Soil EC was determined by EC meter in 1:5 soil water suspensions as indicated by Smith et al [6].

f) Soil Organic Matter: Soil organic matter was determined by the method of Walkley- Black as described by Nelson and Sommers [7].

\section{Results}

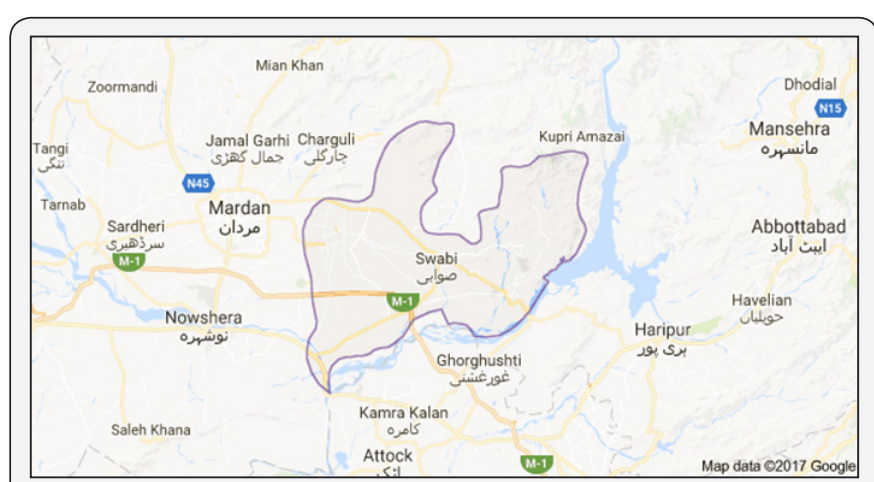

Figure 2 : Sampling area of Peshawar Distract.

Physio-chemical characteristics of different soils vary in space and time due to variation in topography, climate, physical weathering processes, vegetation cover, microbial activities, and several other biotic and abiotic variables. Different factors create different type of soil. The properties of soil along with its type have a great importance in agriculture. Soil physio chemical properties deteriorate to the change in land use especially from agriculture 
and forest. The change in physio-chemical properties of soil leads to infertile or barren soil that does not support normal growth of vegetation for years (Figure 2).

a) Soil Texture: Table 1 shows the texture of two different districts soil. Laboratory analysis of the samples shows that the soil of both the district belongs to the class of loam. Soil of district Swabi contains 30.31\% sand, $43.93 \%$ silt and $26.22 \%$ clay which show that, it is loam. Similarly soil of district Peshawar contains $32.6 \%$ sand, $42.56 \%$ silt and $20 \%$ clay. These percentages shows that the soil belongs class loam. Basically loam is a soil comprised of almost equal amounts of sand and silt and a little less clay (Tables $1 \& 2$ ).

Table 1: Shows the Swabi district Soils percentages.

\begin{tabular}{|c|c|c|c|c|}
\hline Sample No. & Sand \% & Silt \% & Clay \% & $\begin{array}{c}\text { Texture } \\
\text { Class }\end{array}$ \\
\hline 1 & 30.9 & 37.80 & 31.3 & Clay Loam \\
\hline 2 & 39.9 & 47.10 & 13.0 & Loam \\
\hline 3 & 37.00 & 48.0 & 15.0 & Loam \\
\hline 5 & 21.0 & 42.6 & 36.4 & Clay Loam \\
\hline 6 & 25 & 40.5 & 34.5 & Clay Loam \\
\hline 7 & 30 & 36 & 34 & Clay Loam \\
\hline 8 & 39 & 43 & 18 & Loam \\
\hline 9 & 31.8 & 43.8 & 24.4 & Loam \\
\hline 10 & 34.0 & 40.0 & 26.0 & Loam \\
\hline
\end{tabular}

Table 2: Shows the percentages of soils in Peshawar district.

\begin{tabular}{|c|c|c|c|c|}
\hline Sample No. & Sand \% & Silt \% & Clay \% & $\begin{array}{c}\text { Texture } \\
\text { Class }\end{array}$ \\
\hline 1 & 37 & 36 & 27 & Loam \\
\hline 2 & 28.3 & 52 & 19.7 & Silt loam \\
\hline 3 & 37 & 42 & 21 & loam \\
\hline 4 & 39.9 & 39.1 & 21 & Loam \\
\hline 5 & 37 & 35 & 28 & Clay loam \\
\hline 6 & 56 & 37.00 & 7.0 & Sandy loam \\
\hline 7 & 49.10 & 40.2 & 10.7 & Loam \\
\hline 8 & 38.7 & 44.45 & 16.85 & Loam \\
\hline 9 & 38 & 44.50 & 17.5 & Loam \\
\hline 10 & 41.37 & 45.35 & 13.28 & Loam \\
\hline
\end{tabular}

b) Bulk Density: The data regarding soil bulk density of two different districts soil i.e. Swabi and Peshawar are presented in Table 3. The Laboratory analysis of soil samples shows that the average bulk density of Peshawar district is about $1.52 \mathrm{~g} \mathrm{~cm}-3$ while that of Swabi district soil is about $1.61 \mathrm{~g} \mathrm{~cm}-3$ (Table 3).
Table 3: Shows the bulk densities of the soils in District Swabi and Peshawar.

\begin{tabular}{|c|c|c|}
\hline Sample No. & $\begin{array}{c}\text { Bulk Density (Swabi } \\
\text { district) } \text { gcm }^{-3}\end{array}$ & $\begin{array}{c}\text { Bulk Density (Peshawar } \\
\text { district) } \mathbf{g c m}^{-3}\end{array}$ \\
\hline 1 & 1.64 & 1.55 \\
\hline 2 & 1.83 & 1.46 \\
\hline 3 & 1.61 & 1.59 \\
\hline 4 & 1.53 & 1.32 \\
\hline 5 & 1.72 & 1.70 \\
\hline 6 & 1.42 & 1.39 \\
\hline 7 & 1.33 & 1.63 \\
\hline 8 & 1.81 & 1.51 \\
\hline 9 & 1.54 & 1.44 \\
\hline 10 & 1.67 & 1.61 \\
\hline Means & 1.61 & 1.52 \\
\hline
\end{tabular}

c) Moisture Content (\%): The data concerning soil moisture content of two different districts i.e. Swabi and Peshawar are given in (Table 4). Laboratory analysis of the data shows that the mean moisture content of Swabi district soil is $6.56 \%$, while that of Peshawar district is $7.8 \%$.

Table 4: Shows Moisture content (\%) of soils of district Swabi and Peshawar.

\begin{tabular}{|c|c|c|}
\hline Sample No. & $\begin{array}{c}\text { Moisture Content (Swabi } \\
\text { district) }\end{array}$ & $\begin{array}{c}\text { Moisture Content } \\
\text { (Peshawar district) }\end{array}$ \\
\hline 1 & 6.53 & 7.00 \\
\hline 2 & 7.15 & 8.09 \\
\hline 3 & 5.45 & 6.50 \\
\hline 4 & 7.93 & 10.00 \\
\hline 5 & 8.73 & 7.60 \\
\hline 6 & 8.51 & 9.20 \\
\hline 7 & 5.37 & 6.10 \\
\hline 8 & 6.18 & 7.17 \\
\hline 9 & 9.92 & 8.35 \\
\hline 10 & 8.34 & 8.10 \\
\hline Means & 6.56 & 7.8 \\
\hline
\end{tabular}

Table 5: Shows the pH of soils in Peshawar and Swabi.

\begin{tabular}{|c|c|c|}
\hline Sample No. & pH (Peshawar district) & pH (Swabi district) \\
\hline 1 & 6.95 & 7.84 \\
\hline 2 & 7.36 & 7.64 \\
\hline 3 & 7.58 & 7.81 \\
\hline 4 & 7.39 & 7.64 \\
\hline 5 & 7.51 & 7.75 \\
\hline 6 & 7.25 & 7.90 \\
\hline 7 & 7.63 & 7.86 \\
\hline 8 & 7.52 & 7.77 \\
\hline 9 & 6.97 & 7.65 \\
\hline 10 & 7.42 & 7.72 \\
\hline Means & 7.4 & 7.7 \\
\hline
\end{tabular}


d) Soil pH: Table 5 shows pH of two different districts soil. Laboratory analysis of the data stated that the average $\mathrm{pH}$ of Peshawar district is about 7.4 and $\mathrm{pH}$ of Swabi district is 7.7. $\mathrm{pH}$ of both districts is neutral and quite suitable for agricultural crops.

e) Electrical conductivity (EC): Table 6 shows the soil EC of two different districts soil i.e. Swabi and Peshawar. Laboratory analysis of the data shows that the average EC of Peshawar district is $0.204 \mathrm{dSm}^{-1}$ and that of Swabi district is $0.158 \mathrm{dSm}^{-1}$. The EC of soils varies depending on the amount of moisture held by soil particles. Sands have a low conductivity, silts have a medium conductivity, and clays have a high conductivity. Consequently, EC correlates strongly with soil particle size and texture.

Table 6: Shows the Electrical Conductivity of Soils in District Swabi and Peshawar.

\begin{tabular}{|c|c|c|}
\hline Sample No. & $\begin{array}{c}\text { EC (Swabi district) } \\
\mathbf{d S m}^{-\mathbf{1}}\end{array}$ & $\begin{array}{c}\text { EC (Peshawar } \\
\text { district) } \mathbf{d S m}^{-1}\end{array}$ \\
\hline 1 & 0.175 & 0.288 \\
\hline 2 & 0.113 & 0.202 \\
\hline 3 & 0.127 & 0.259 \\
\hline 4 & 0.186 & 0.168 \\
\hline 5 & 0.168 & 0.206 \\
\hline 6 & 0.152 & 0.200 \\
\hline 7 & 0.192 & 0.182 \\
\hline 8 & 0.154 & 0.197 \\
\hline 9 & 0.169 & 0.187 \\
\hline 10 & 0.141 & 0.252 \\
\hline Means & 0.158 & 0.204 \\
\hline
\end{tabular}

Table 7: Shows SOM (\%) in district Swabi and Peshawar.

\begin{tabular}{|c|c|c|}
\hline Sample No. & $\begin{array}{c}\text { SOM (Swabi } \\
\text { district) }\end{array}$ & $\begin{array}{c}\text { SOM (Peshawar } \\
\text { district) }\end{array}$ \\
\hline 1 & 0.12 & 0.68 \\
\hline 2 & 0.45 & 0.74 \\
\hline 3 & 0.34 & 0.66 \\
\hline 4 & 0.15 & 0.94 \\
\hline 5 & 0.47 & 0.50 \\
\hline 6 & 0.38 & 0.78 \\
\hline 7 & 0.16 & 0.64 \\
\hline 8 & 0.35 & 0.72 \\
\hline 9 & 0.21 & 0.90 \\
\hline 10 & 0.18 & 0.76 \\
\hline Means & 0.26 & 0.70 \\
\hline
\end{tabular}

f) Soil Organic Matter (\%): The data concerning soil organic matter of two different districts soils are shown in Table 7. The laboratory analysis of the data shows that the soil of both the districts has less amount of organic matter which is essential to improve the fertility of soil and hence crop yield. Although the amount is low the highest amount of organic matter was recorded in the soil of Peshawar district (0.702 \%) while in the soil of Swabi District (0.26\%) amount of organic matter was recorded.

\section{Conclusion}

This study concludes that there are no major differences between the soil physio-chemical properties of the two districts, but slight differences exist. The differences are may be due to agricultural practices, irrigation system, use of fertilizers or may be due to some natural conditions. The soil properties are quite in normal and good for normal agricultural activities.

\section{Recommendations}

We all know that soil is a key element of agriculture. Without it we wouldn't be able to grow plants, which are used as food for both humans and animals. Soil quality is the capacity of a specific kind of soil to function within natural or managed ecosystem boundaries, sustain plant and animal productivity, maintain or enhance the quality of water and air, and support human health and habitation. For sustainability of soil quality old agricultural practices should be discouraged and new practices and techniques should be adopted. The areas where the soil are acidic lime or gypsum treatment should be given for normal productivity or the areas where the soil are alkaline artificial fertilizes should be used to neutralize it. Artificial fertilizers should be used in the required range as it excess May also not good for soil well as for crops. Good irrigation system should be established and manure and other natural organic materials should be added to soil to maintain its humus. Crop rotation should be in proper manner to maintain the soil physio-chemical properties in normal range and soil quality in good condition.

\section{Acknowledgements}

The authors are very much thankful to the department of Environmental Sciences, University of Peshawar for providing facilities and relevant supervision during this research study.

\section{References}

1. World Health Organization and Research for International Tobacco Control. WHO report on the global tobacco epidemic, 2008: the MPOWER package? World Health Organization, USA.

2. UN (2008) World Population Prospects: The 2008 Revision, Volume III. United Nations Department of Economic and Social Affairs, New York, USA.

3. Khan F, Ahmad W, Bhatti AU, Khattak RA (2003) Effect of soil erosion on physical properties of some soil series in NWFP, Pakistan. Pakistan Journal of Soil Science 22(1): 36-42.

4. Khan F, Ahmad W, Bhatti AU, Khattak RA, Shafiq M (2004) Effect of soil erosion on chemical properties of some soil series in NWFP, Pakistan. Science Technology and Development 23(4): 31-35.

5. Gee GW, Bauder JW (1986) Particle-size analysis. Methods of soil analysis: Part 1-Physical and mineralogical methods, (methods of soil an1) pp. 383-411. 
6. Smith JL, Doran JW (1996) Measurement and use of pH and electrical conductivity for soil quality analysis. Methods for Assessing Soil Quality. Soil Science Society of America (SSSA). Special Publication.
7. Nelson, DW, Sommers, LE (1996) Total carbon, organic carbon, and organic matter. Methods of soil analysis part 3-chemical methods, (methods of soil an3) pp. 961-1010.

This work is licensed under Creative Commons Attribution 4.0 Licens

DOI: 10.19080/IJESNR.2017.07.555710
Your next submission with Juniper Publishers will reach you the below assets

- Quality Editorial service

- Swift Peer Review

- Reprints availability

- E-prints Service

- Manuscript Podcast for convenient understanding

- Global attainment for your research

- Manuscript accessibility in different formats

(Pdf, E-pub, Full Text, Audio)

- Unceasing customer service

Track the below URL for one-step submission

https://juniperpublishers.com/online-submission.php 